\title{
The Impact of Remittances on Kyrgyzstan Economy
}

\author{
Ph.D. Candidate Kiyalbek Akmoldoev (International Ataturk Alatoo University, Kyrgyzstan) \\ Mrs. Aidai Budaichieva (International Ataturk-Alatoo University, Kyrgyzstan)
}

\begin{abstract}
Data of the worker's remittance flow in the period of 2000-2010 were employed to analyze the impact of remittances on macroeconomic indicators of the Kyrgyz Republic. Focus was given to the assessment of remittance effect on economic effectiveness. To study the underlying issue, linear correlation method and economic performance effectiveness index were used. Results showed that great portion of remittances has been directed into consumption rather than to investment. Moreover, remittance spending is channeled into consumption of imported goods, thus raising the trade deficit of a country. Their impact on economic effectiveness of Kyrgyzstan presents that given the low propensity to invest, they finance consumption and cause high consumption ratio with respect to investment ratio, thus leading to reduction of economic effectiveness.
\end{abstract}

JEL codes: F22, O15, F36

\section{Introduction}

Remittances - funds sent by migrant workers to their relatives in home countries — are an increasingly important source of external finance for low income countries especially for the many small economies. The officially recorded inflow of remittances to developing economies has grown from $\$ 56$ billion in 1995 to $\$ 334$ billion in 2010 (World Bank 2010). For some countries, remittances can be as high as a half of GDP. Remittances also now account for about a third of total global external finance; moreover, the flow of remittances seems to be significantly more stable than that of other forms of external finance.

The concept of remittances derives from the theories of migration of various economic though (developmentalists, structuralists, New Economics of Labor Migration), that have different viewpoints on migration and remittances. Given framework of the above mentioned theories a great deal of academic studies had been conducted on impact of remittance on economy.

The participation of Kyrgyzstan in labor migration process with CIS and other foreign countries is aligned with export of labor. The process of labor migration in Kyrgyzstan emerged as a result of transformation process into market economy. According to different estimates there are more than 950 thousand Kyrgyz citizens are working overseas. Official central bank statistics show significant amounts remittances being transferred -up to $28.8 \%$ of GDP in the Kyrgyz Republic.

However, very little is known about the structure of remittance flows in terms of channels of remittance transfers and, perhaps more importantly, effects of remittances on economy. This lack of information prevents both governments and financial institution from responding with policy changes to increase remittance inflows and their positive effects on socio-economic development and poverty reduction.

The research analyzes the volume of remittances of Kyrgyz migrant laborers made from abroad and their impact on macroeconomic indicators of the country. The key question of concern for study is: Do remittances contribute to sustained improvements in economic development of the Kyrgyz Republic? The two main questions of interest to policymakers with regard to remittances are: How to manage the macroeconomic effects of remittances? How to harness the development potential of remittances?

The aim of the study is to examine an impact of remittances on economy of Kyrgyzstan. To explore the topic of concern the following tasks are proposed:

- To determine the nature and causes of remittances and their macroeconomic impact

- To analyze the magnitude of remittances and their impact on macroeconomic indices and economic effectiveness of Kyrgyzstan.

- To determine problems of remittances in current conditions of Kyrgyzstan

- To present a role of policymakers in macroeconomic management of remittances and suggest some policy implications

\section{Macroeconomic Impact of Remittances}

Macroeconomic studies indicate that although migrants' remittances are affected by the economic cycles of source and host countries, they often provide a significant source of foreign currency, finance imports and contribute to the balance of payment, increase national income.

Perhaps the most common reason for skepticism on migration and development has been the widespread belief that migrants rarely invest their money in productive enterprises, but instead spend it on consumption or nonproductive investments (Massey et al. 1998; Adams 1991; Taylor 1999; Woodruff and Zenteno 2007). Besides, if 
spent on imported consumer goods rather than locally produced ones, the potential multiplier effect may decrease while simultaneously increasing import demand and inflation. This has the effect of making exports less competitive, while stimulating imports. However, most studies seem to suggest that households receiving international remittances have a higher propensity to invest than non-migrant households when controlling for income and other relevant household variables. Other case studies indicated signs that remittances may indeed have served to accelerate investment in Morocco and perhaps in India. More generally, Glytsos (2001) estimates a simple dynamic, simultaneous model of aggregate investments, consumption, imports and the feedback of these components through GDP, for seven Mediterranean countries from about 1969 to 1993. Simulating the direct and indirect effects of remittances on incomes and hence on investment through this framework, Glytsos finds that over a six year period investment rises with remittances in six out of the seven countries, and in four of these investment rises by more than the initial amount remitted .

The impact of remittances can be explored along pricing of goods. Sudden riches can create many problems for an economy, and remittance-driven gains are no exception. Remittances are foreign-earned money that can raise the cost of goods in the recipient-country. The recipient country has not increased production, yet there is more money in circulation owing to the remittances; hence, prices rise. If the nation-state is seen in isolation, then such price increases owe themselves not to any improvement in the economy, but to an exogenousarguably false-increase in purchasing power. Recipient economies flush with remittance money become vulnerable both to inflation, particularly harmful to those not receiving remittances, and, through labor reduction, to falling exports as the economy reacts to the increased remittances . Large remittance inflows, like any large influx of foreign currency, can lead to appreciation of the local currency. Hence, an appreciation of the exchange rate generates a resource allocation from the tradable to the no tradable sector. This phenomenon is usually labeled as the «Dutch disease».

To date, the empirical evidence of the impact of remittances on economic growth appears mixed. For instance, results for a sample of 39 developing countries covering the period 1980-2004 indicate a positive impact on economic growth. A study examining the aggregate impact of remittances on the economic growth of 18 Latin American countries for the period 1980-2005 found that remittances positively and significantly affected the growth of Latin American economies where the financial systems are less developed by providing an alternative way to finance investment and helping overcome liquidity constraints. On the other hand, empirical assessments on the impact of workers' remittances on growth and poverty reduction in developing Asia-Pacific countries for the period 1993-2003 found that, "while remittances do have a significant impact on poverty reduction through increasing income, smoothing consumption and easing capital constraints of the poor, they have only a marginal impact on growth operating through domestic investment and human capital development". While not denying the poverty alleviating and consumption smoothing effects of remittances on recipient households, other studies find no impact on economic growth (UNESC, 2010).

\subsection{Theoretical underpinnings of remittances}

When remittances constitute a significant source of foreign exchange, they may clearly affect the equilibrium level of the gross national product and other macroeconomic variables. Possible theoretical treatment of remittances was made by Kireyev, while analyzing the impact of remittances on economy of Tajikistan. He suggested the Keynesian approach to describe effect of remittances on macroeconomic indicators (Kireev, 2006).

\subsection{The Keynesian model}

Driven by remittances, an increase in income and therefore demand has a magnified effect on real GDP growth. The magnification depends on the multiplier and the size of remittances. The multiplier itself depends on marginal propensities to import and to save. In the classic Keynesian model investment (I) and exports (X) are completely autonomous from the level of output (Y). Therefore, an increase in a country's overall income by way of remittances $(\mathrm{R})$ can be represented either as an autonomous increase in export receipts or as additional investment. Savings (S) and imports (M) consist of an autonomous component independent of Y, and an income induced component. In a spending-output space, where $S$ and $\mathrm{M}$ are seen as leakages and $\mathrm{I}$ and $\mathrm{X}$ as injections, an additional inflow $\mathrm{R}$ will initially lead to an increase in equilibrium output from $\mathrm{A}$ to $\mathrm{B}$.

However, the final equilibrium will crucially depend on the impact of $\mathrm{R}$ on the marginal propensities to import (m) and to save (s). Most likely, both will also increase, and the associated leakage will push the final equilibrium back from $B$ to $C$, with the output level only marginally higher than the original. If $m+s=1$, the Keynesian multiplier equals unity, and the whole amount of $\mathrm{R}$ will be leaked with $\mathrm{Y}$ unchanged. The more open the economy, the smaller the multiplier and the less significant the impact of remittances on output.

\section{Economics of Remittances in Kyrgyzstan and its Magnitude}

Obviously, dynamics and scale of labor migration give rise to issue of remittances, particularly their impact on small economy of Kyrgyzstan current conditions. During aggravating transition period of Kyrgyzstan remittances have adversely affected the overall economic development, although remittances represent safety net on individual households. 


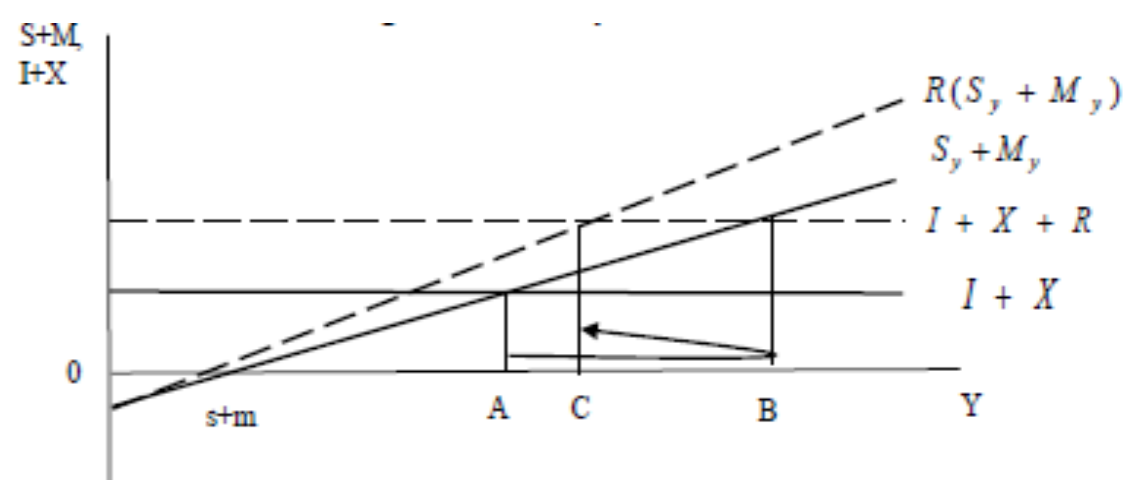

Figure 1. The Keynesian Model Source: Kireev 2006

\begin{tabular}{|l|l|l|l|l|l|l|l|l|}
\hline year & 2003 & 2004 & 2005 & 2006 & 2007 & 2008 & 2009 & 2010 \\
\hline remittances & 112.7 & 285.4 & 481.5 & 730.6 & 1021.1 & 1468.7 & 1072 & 1379.3 \\
\hline
\end{tabular}

Table 1. Remittances flow dynamics in Kyrgyzstan (mln. US dollars) Source: National Bank of Kyrgyz Republic, 2011

The remittance flow for the last decade has been increasing steadily. Moreover, it has been more than doubling annually in average.

In 2009 remittance flow decreased by $27 \%$ due to the world financial crisis, which affected economies of Russia, and Kazakhstan. This data do not take into account informal transfers of funds, which are part of the "errors and omissions" section of Balance of payments. The rapid growth in volume of this section from 2003 is linked to the constant growth of informal channeling of remittances (Bespalov, 2009). Although, in the world practice the remittances are being the most stable source of external finance remittance flow in Kyrgyzstan stay volatile to external shocks. The remittances volatility index in 2010, computed as a standard deviation of the ratio of relevant inflow to GDP almost the same as FDI volatility index. It can be explained by the fact that the number seasonal labor migrants by far exceed permanent workers.

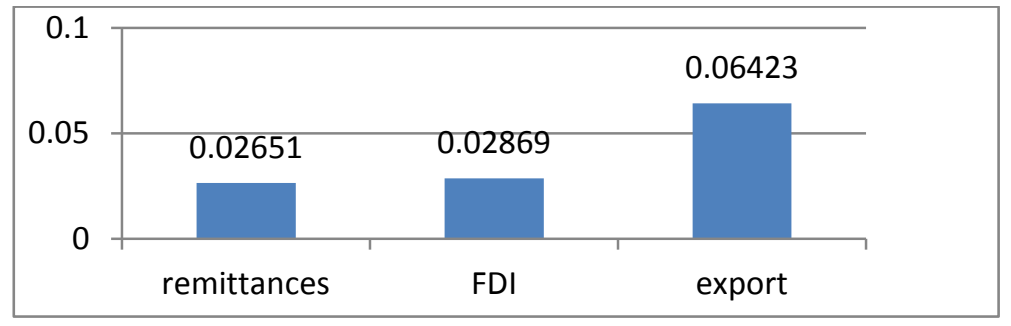

Figure 2. Volatility indexes of remittances, FDI and export of Kyrgyzstan Source: National Statistics Committee and National Bank of Kyrgyz Republic, own calculations, 2010

According to annual report of National Bank of Kyrgyz Republic of 9th month of 2011 remittance flow was remitted from Russia (93, 9\%), Kazakhstan (2,4\%), and the USA (2,3\%).

As it was mentioned, remittances comprise a significant share of GDP. According to World Bank, in 2008 Kyrgyzstan was among top 10 countries with remittances amounting large share of GDP (28\%) and took the forth place followed by Tajikistan, Tonga, and Republic of Moldova. After the recovery of world financial crisis, in 2010 , remittances increased and reached $28.8 \%$ as a share of GDP.

Currently, there are no sufficient systematic researches on remittances impact on economy of Kyrgyzstan. There is just few researches conducted regarding remittances. One of them was conducted by Samagan Aitymbetov, Economic Policy Institute, 2005; the other by Bespalov A.D. (2009). In the first research the data of National Bank of Kyrgyz Republic was used and the main conclusion of which was that remittances have positive impact on socio-economic development and poverty reduction in Kyrgyzstan. Bespalov in his work states that remittances effect on economy of Kyrgyzstan by positive impact on GDP and private consumption, have an impact on rise of import volume, have almost no impact on investment; increases the marginal propensity to consume of remittance receiving households, and have positive impact on socio- economic condition of Kyrgyzstan.

Remittances can have a potential impact on some macroeconomic indices of Kyrgyzstan such as consumption and import. The impact of remittances to private consumption is a measure of the extent to which remittances can be used to finance private consumption of domestic inhabitants. Almost $70 \%$ of remittances are spent on consumption (Aitymbekov, 2005). The correlation of remittances with private consumption is $97 \%$ (Figure 3). 


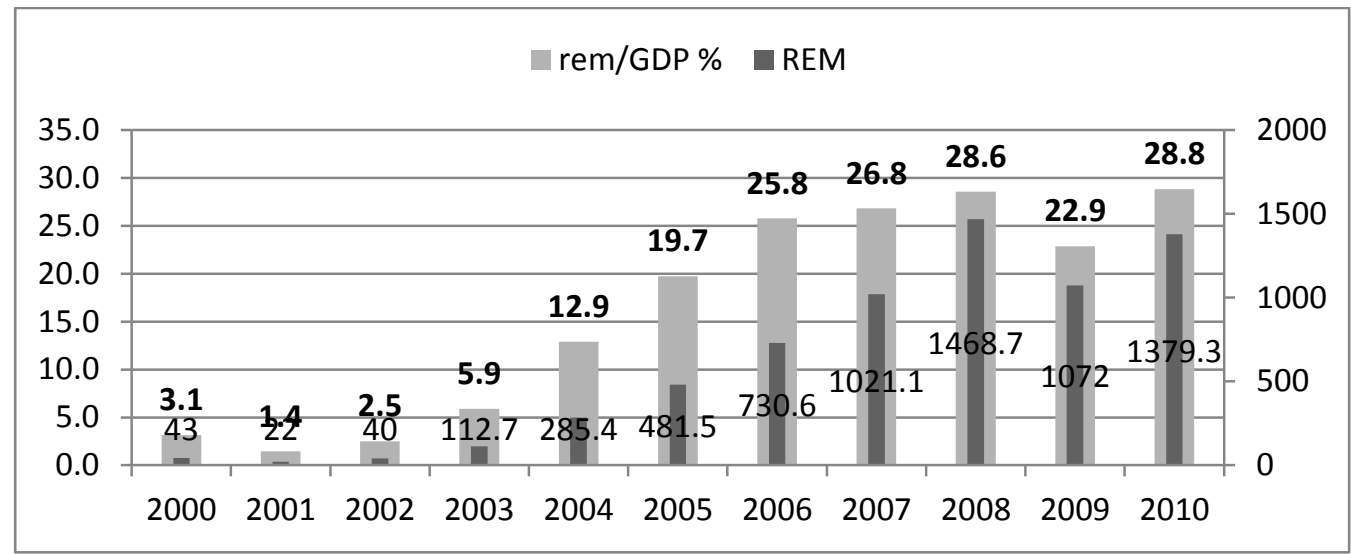

Figure 3. Remittances as a share of GDP (2000-2010) Source: National Statistic Committee, National Bank, own estimations, 2011

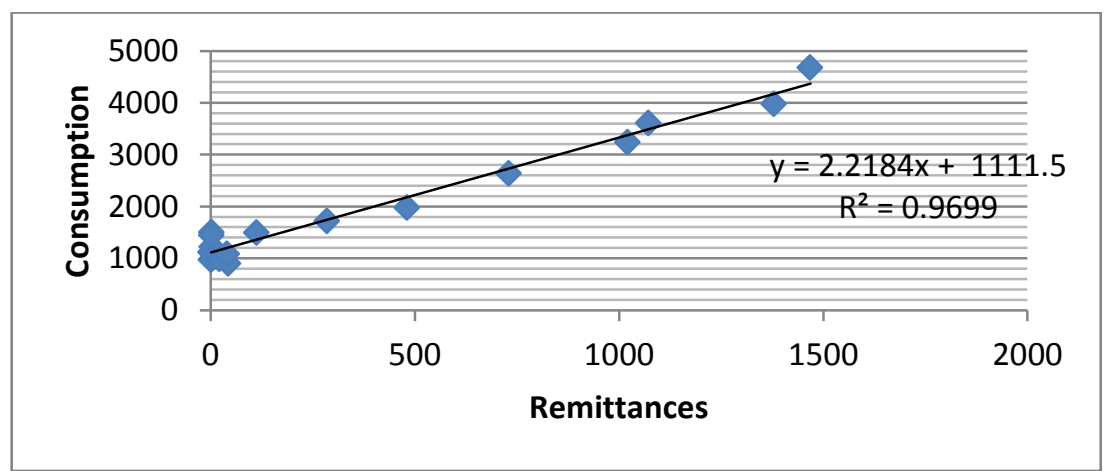

Figure 4. Correlation of remittances with private consumption of Kyrgyzstan (1995-2010) Source: National Bank and National Statistics Committee of Kyrgyz Republic, 2011



Figure 5. Remittances and import dynamics (2001-2010) Source: National Bank and National Statistics Committee of Kyrgyz Republic

\begin{tabular}{|l|l|}
\hline Correlation of remittances with import & $\mathrm{R}^{2}=0.9808$ \\
\hline Correlation of remittances with time & $\mathrm{R}^{2}=0.9066$ \\
\hline
\end{tabular}

Table 2. Correlation indices of remittances with import and time Source: National Bank and National Statistics Committee of Kyrgyz Republic, 2011

It is obvious that the share of imported goods in consumption is very large in Kyrgyzstan. For this reason it is reasonable to conclude that remittances finance imported goods. The correlation index $\mathrm{R}^{\wedge} 2$ is $98 \%$, meaning that import of Kyrgyzstan is dependent on the remittance flow.

Remittances have increasing pattern year by year. Thus it can be concluded that remittances steadily finance the consumption of imported goods.

Remittances have not much impact on investment. Despite the fact that remittances can be associated with savings in a way that rise in remittances lead to the increase in savings, its increase can not necessarily bring to rise in investment. Most of the households in Kyrgyzstan prefer to save in a way of buying real estate, which cause rise of apartment's price in Bishkek and Osh in recent years. Besides, quick withdrawals of remitted funds and low level of investing in business by receivers permit to draw a conclusion that the degree of remittances impact on investment stays low. 
In order to see complete reflection of the impact of remittances on economy of Kyrgyzstan it is reasonable to calculate an index of economic effectiveness, which identifies the level of economic development. The Economic Development Institute (EDI) of World Bank uses this index as an international method of computing countries level of socio-economic development, which show how factors of production (in our case - labor resources) effect economic development of a country.

The index of economic effectiveness is computed by the ratio of aggregate labor costs for given period of time (GDP) and aggregate costs of all factors of production to same period of time. The higher an index of economic effectiveness, the higher is the level of economic development of a country

$$
\text { I5 }=\frac{\text { GDP }}{\text { where, I5= index }}
$$

Aggregate costs are the sum of all costs of goods and services produced in a country for a given year. Aggregate costs of production comprise aggregate consumption, aggregate investment, aggregate government expenditures and aggregate net export.

The impact of remittances on the economic effectiveness index of Kyrgyzstan was presented by Bespalov A.D. in his work "Labor migration as a factor of socio-economic development (in case of Kyrgyzstan)". He has estimated this index for 3 years from 2005 to 2007.

As a matter of fact that there is no data on aggregate costs of all factors of production, he proposed the following method of computing: since aggregate costs are costs of production of goods and services, they can be calculated by subtracting from revenue of the goods and services sold (GDP) the value added tax (VAT) and other duties (20\%). Because GDP consists of 4 components: consumption, investment, government expenditure and net export, the aggregate costs of production must be calculated by each of components separately in a following way:

Aggregate cost of consumption = consumption $-20 \%$ of consumption

Aggregate cost of investment $=$ investment $-20 \%$ of investment

Aggregate cost of government expenditure $=$ gov-t expenditure $-20 \%$ of gov-t expenditure

Aggregate cost of net export $=$ net export $-20 \%$ of net export

The sum of the factors costs of production of each GDP components represents aggregate cost of production. To derive an index of economic effectiveness GDP must be divided by the aggregate cost of production. If an index of economic effectiveness is more than 1, an economy is considered as effective and the higher this index the higher is the level of economic development.

Bespalov computed the impact of remittances on the economic effectiveness of Kyrgyzstan till 2007 and found out that economy of Kyrgyzstan is effective since the economic effectiveness index is more than 1 . However, during considered time period the degree of economic activity in Kyrgyzstan was decreasing despite growing remittance flow (Bespalov, 2009). He explains such dynamics as a consequence of rise in consumption, and relatively small investments within increasing flow of remittances. Given this outcomes it is reasonable to continue the estimation till 2010 and analyze economic effectiveness and impact of remittances on economic performance of Kyrgyzstan.

Estimation results show that an index of economic effectiveness is more than 1, meaning that economy of Kyrgyzstan is effective. In 2009 the economic effectiveness rises. It can be explained by the outcome of world financial crisis that caused a substantial reduction of remittances (by 29\%) and hence private consumption. In 2010 an economic effectiveness dropped again.

\begin{tabular}{|l|l|l|l|}
\hline & \multicolumn{1}{|c|}{$\mathbf{2 0 0 8}$} & \multicolumn{1}{c|}{$\mathbf{2 0 0 9}$} & \multicolumn{1}{c|}{$\mathbf{2 0 1 0}$} \\
\hline GDP & 187991.9 & 201222.9 & 220369.3 \\
\hline private consumption & 171294.6 & 154886.9 & 183324.7 \\
\hline government expenditure & 32937.5 & 37088.5 & 39946.5 \\
\hline Investment & 54421.7 & 54874.2 & 60384.7 \\
\hline Aggregate consumption & 34258.92 & 30977.38 & 36664.94 \\
\hline Aggregate government expenditure & 6587.5 & 7417.7 & 7989.3 \\
\hline Aggregate investment & 10884.34 & 10974.84 & 12076.94 \\
\hline Total aggregate cost of factors of production & $\mathbf{5 1 7 3 0 . 7 6}$ & $\mathbf{4 9 3 6 9 . 9 2}$ & $\mathbf{5 6 7 3 1 . 1 8}$ \\
\hline index of economic effectiveness (I5) & $\mathbf{3 . 6 3 4 0 4 5}$ & $\mathbf{4 . 0 7 5 8 2}$ & $\mathbf{3 . 8 8 4 4 4 8}$ \\
\hline
\end{tabular}

Table 3. Index of economic effectiveness of Kyrgyzstan (2006-2010) Source: National Statistics Committee of Kyrgyz Republic, own estimations, 2011 


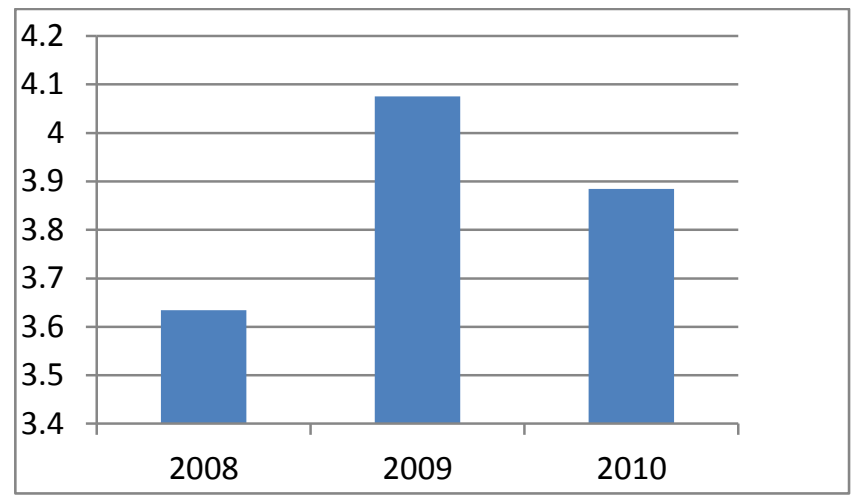

Figure 6. Dynamics of an index of economic effectiveness (I5) of Kyrgyzstan. Source: own estimations

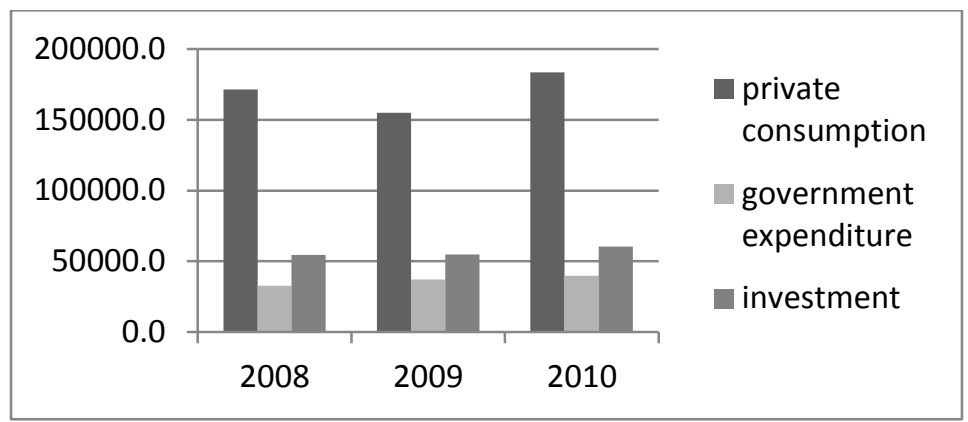

Figure 7. GDP, private consumption, government expenditure, investment dynamics (2006- 2010) Source: National Statistics Committee of Kyrgyz Republic, 2011

The figures 6 and 7 show the impact world financial crisis on economic effectiveness. In 2009 remittance flow in Kyrgyzstan dropped. Therefore, private consumption also decreased; while the level of investment in 2009 stays relatively the same as in 2008 (figure 6). Under such circumstances index of economic effectiveness in 2009 increased. In 2010, with the recovery from crisis and increasing remittances, hence consumption the index of economic effectiveness dropped again.

Thus, analysis of remittances impact on economic effectiveness of Kyrgyzstan presents that given the low propensity to invest, remittances finance consumption and leads to its higher consumption ratio with respect to investment ratio.

A serious drawback of remittances flow in Kyrgyzstan is that they are not channeled into investment uses. However, as a means of consumption remittances represent a safety net; hence increase a purchasing power of receiving individual households.

\section{Conclusion}

Analysis of the impact of remittances on Kyrgyz economy enabled to draw a conclusion that remittances have minimal negative spillovers in economies whose marginal propensity to invest is high and they are unlikely to have any lasting impact on growth in countries with high marginal propensity to consume. The latter is peculiar for economy of Kyrgyzstan. A great portion of remittances is directed into consumption rather than in investment. More importantly, remittances use in Kyrgyzstan is channeled into consumption of imported goods, thus raising the trade deficit of a country.

Remittances impact on economic effectiveness of Kyrgyzstan presents that given the low propensity to invest, remittances finance consumption and cause high consumption ratio with respect to investment ratio, thus leading to reduction of economic effectiveness. Appling a Keynesian model approach for Kyrgyzstan, although the lack of marginal propensity to save data, low bank consumer deposits and quick withdrawals of remittances; booming imports, particularly in recent years, in parallel with growing inflows of remittances, spent on (imported) consumption suggest that there is almost no multiplier effect. The impact on growth depends on the interaction between the magnitude of net remittances and the unknown marginal propensity to save. Besides, remittances are not channeled into the production, and hence they do not finance export. Under this approach, the impact of remittances on growth is likely to be small. Thus, more open the economy, the smaller the multiplier and the less significant the impact of remittances on output.

Thus, a serious drawback of remittances flow in Kyrgyzstan is that they are not channeled into investment uses. However, labor migration and flow of remittances have played a significant role in increasing consumption and reducing poverty in Kyrgyzstan. This has had a significant impact on the balance of payments and has 
helped to smooth the economic and social impact of transition. However, given the size of the phenomenon, it also implies some risks, as a large proportion of the labor force has left the country.

Part of the reason why remittances have not encouraged economic development is that they are generally not intended to serve as investments but rather as social insurance to help family members finance the purchase of life's necessities. Remittances lift people out of poverty but they do not typically turn their recipients into entrepreneurs. The intriguing possibility remains that remittances can be channeled somehow into achieving both of these ends, but this will require a better understanding of the role that remittances play in their recipients' lives, and institutions that can help recipients of remittances make the most of the transfers they receive.

The authorities should continue to give careful consideration to the implications of such remittances on the implementation of monetary and exchange rate policies, and in the context of the evolution of the balance of payments. Although the high level of remittances has underpinned a social security, this source of development should not detract the authorities from the urgency of reform. The authorities, together with their development partners, need to come to a judgment as to whether or not remittances are likely to be a permanent phenomenon in Kyrgyzstan. Also, conducting a comprehensive survey to assess the actual scale of remittances and labor migration would help the authorities to develop a well-defined strategy to maximize the benefits of remittances be increasing the productive investments and minimize any negative consequences.

All in all, we should not forget one crucial misconception. Remittances are not a development model - but rather a sign of the failure of development.

\section{References:}

- Bespalov D. A. (2009) “Analysis of remittances and their impact on GDP of Kyrgyz Republic"; Vestnik KRSU;2009, \#8, p36

- $\quad$ Bespalov D.A. (2009) "Labor migration as a factor of socio-economic development (in case of Kyrgyzstan); Kyrgyzstan, Bishkek" 2009, p 19

- Glytsos, (2001) "Dynamic Effects of Migrant Remittances on Growth: An Econometric Model with an Application to Mediterranean Countries", Athens, Greece: Center of Planning and Economic Research, 2001

- $\quad$ Kireev.A (2006) “The macroeconomics of remittances: the case of Tajikistan", IMF Working Paper WP/06/2,International Monetary Fund, 2006;p 19

- $\quad$ Massey et al. 1998; Adams 1991; Taylor 1999; Woodruff and Zenteno 2007; de Haas 2006. Cited by Hein de Haas, Remittances, migration and social development: a conceptual review of the literature,2007,p 14

- Puri and Ritzema, Migrant Worker Remittances, Micro-finance and the Informal Economy: Prospects and issues; Working paper No. 21, International Labor Office (ILO), Geneva.1999.

- Samagan Aitymbekov, (2005) "Emigrant remittances: Impact of remittances on economic development of Kyrgyzstan”, 2005; p.21

- United Nations Economic and Social Commission for Asia and the Pacific, 'External Financing in South Asia: The Remittances Option', 2010, ARTNeT Policy Brief, No. 23, Bangkok, p 127

- $\quad$ http://www.nbkr.kg/index1.jsp?item=138\&lang=RUS, Payments of balance NBKR, 14.06.2012

- $\quad$ http://stat.kg/index.php?option=com content\&task=view\&id=25\&Itemid=101, National Accounts, National Statistics committee of Kyrgyz republic. 14.06.2012

- http://www.worldbank.org/migration 